\title{
Impact of Coal Mining in Diversification of Rural Livelihoods: A Case Study in the Barjora Colliery Area of Bankura District, West Bengal
}

Rakesh Banerjee $^{+*}$ and Dr Biswaranjan Mistri ${ }^{i}$

\section{Abstract}

Coal mining plays a key role in developing the economic backbone of many developing countries, such as India, although on a local scale. Coal mining industries enormously influence the surrounding environments and livelihoods. An open cast coal mine severely enhances the dust particles in the local atmosphere over time and in turn, affects the fertility of the surrounding lands.

Additionally, the socio-economic conditions of the local community go through a massive perturbation due to land acquisition, migration of people and insecurity of jobs. In this present work, an effort has been made to understand the effect of open cast coal mining on the diverse livelihoods of the rural community in Barjora colliery area of West Bengal. The livelihood pattern of the local community has significantly changed from pre-mining to post-mining, such as in agriculture sector, the work participation rate has reduced from $62 \%$ to $3 \%$, and at present, about $55 \%$ people are now engaged in the mining sector. The immediate effect helped to increase the financial capacity of rural people. However, the upward socio-economic condition is not sustainable for the long-term. The discontinuity in coal extraction is also the major cause for the job insecurity and vulnerability in socio-economic life.

Keywords: Barjora Colliery, Open Cast Coal Mining, Diversify Rural Livelihood, Unsustainable Livelihood, West Bengal

\footnotetext{
${ }^{\dagger}$ M.Phil. in Geography, Department of Geography, The University of Burdwan, Burdwan- 713104, West Bengal, India ${ }^{*}$ Corresponding Author, Email: rakeshbanerjee7@gmail.com

${ }^{\imath}$ Associate Professor, Department of Geography, The University of Burdwan, Burdwan- 713104, West Bengal, India, Email: brmistri@gmail.com

C2019 Banerjee \& Mistri. This is an Open Access article distributed under the terms of the Creative Commons Attribution License (http://creativecommons.org/licenses/by/2.0), which permits unrestricted use, distribution, and reproduction in any medium, provided the original work is properly cited.
} 


\section{Introduction}

Each resource based developmental work provides better infrastructure and economic improvement of the locality. As coal is one of the most highly demanded fossil fuels of the world, coal mining industries are well-known to shape the economy of a country. India is the third largest producer of coal in the world, producing 639.23 metric tons (MT) in 2015-2016 (CMPDI, 2016). The coal mining industry generates colossal measures of revenue and electricity for the country. It gives around $30 \%$ of the worldwide essential vitality need and $41.1 \%$ of the world's power utilisation. It is a fundamental component in above $70 \%$ of the world's steel generation (World Coal Association, 2015). Modern-day open cast coal mining shares maximum concentration in India - it is about $92.74 \%$ of the total coal production in the country (CMPDI, 2016). It not only influences the economic development but also it has an adverse effect on the surrounding ecology as well as familiar to perturb the livelihoods of the local inhabitants (Kitula, 2004). It is often characterised by the loss of livelihood opportunities, land acquisition problem, displacement, environment pollution, loss of biodiversity, and so on (Das and Mishra, 2015: a). According to Jones (1993, p. 179), "the majority of coal-related projects have [the] potential to affect the environment to a significant degree. Opencast methods of coal extraction can directly affect terrestrial and aquatic ecosystems." With the opening of coal mining projects, several socio-economic issues have emerged-such as jobless, land acquisition, reduction of cropland, health problems, an increase of landless farmers, displacement, etc. The rural inhabitants are entirely reliant on land to keep up their livelihood. But the expansion of mining activities is not only displacing them from their major sources of livelihood but at the same time, forcing them to become landless farmers (Oskarsson, 2011). In 2015, scholars like Siddiqui and Lahiri-Dutta estimated that more than $42 \%$ (an estimated 1.4 million) mining and quarrying households are marginal or tremendously vulnerable due to their unsecured jobs (Siddiqui and Lahiri-Dutta, 2015). Due to their vulnerability, these households are not only unable to spend sufficiently on their health, education, food, etc. but also they suffer from different health diseases due to unhealthy air quality, dust pollution, noise pollution and low quality of water which are caused by mining (Siddiqui and Lahiri-Dutta, 2015). Central to this research is to examine the impact of coal mining in the diversification of rural livelihoods. As per Chambers and Conway (1992, p. 6), "a livelihood comprises the capabilities, assets (stores, resources, claims and access) and activities required for a means of living". In India, rural people engage in diversified economic activities to sustain their livelihood (Scoones, 1998). Livelihood diversification is defined as the procedure by which rural families engage in different economic activities and build a 'diverse portfolio of activities' to support their livelihood and to upgrade prerequisites of staying (Ellis, $1998, \mathrm{p}$ 38). It is also a great support to the households when they fail to generate income from the primary source of livelihood. It is directly associated with household livelihood security (Frankenberger, 1996).

Diversifying livelihood framework is less vulnerable instead of non-diversified vocations (Das and Mishra, 2015: b). Diversification policy among rural people helps to stabilise income, and food security, which in turn is reckoned to reduce environmental risk (Reardon et al., 1992). The present study analyses the positive and negative impacts of coal-mining on the diverse rural livelihoods of the local people in Barjora coalfield area in the Bankura district of West Bengal. To examine the effect of coal mining, a comparative analysis is conducted between premining and post-mining conditions of mining communities. As the coal mining industry began in Barjora colliery area in 2010 so the year 2010, is the structural paradigm shift of coal mining activity, and is being considered as the premining and post-mining season. Mining community refers to the people who are directly affected by mining. It includes land donor 
people, local mining workers, displaced people, and residents that live near to the mining plot. Non-mining communities refer to those people who are not straightforwardly influenced by mining. They are alternate villagers whose lands are not occupied by the mining authorities (Kitula, 2004).

The article begins with a review of the literature and the conceptual framework. Following this, the study outlines the major research questions and objectives including a detailed description of the study area wherein the backgrounds of the collieries are presented. The study concludes after in-depth analysis and interpretation of the research questions.

\section{Research Questions}

The main research questions addressed in this research work are:

- how coal-mining activity influences the livelihoods of the local people in the study area and

- what are the socio-economic changes caused by coal-mining activity in the study area.

\section{Objectives}

This research work has dealt with the study of changing livelihood pattern due to the introduction of open cast coal mining activity in Barjora coal-field area, covering two prime objectives:

- to analyse the impact of coal mining on diversified livelihood pattern across the pre-mining and post-mining condition of affected communities and
- to examine the perception of the local communities on how coal mining activities impact the major socioeconomic activities in the study area.

\section{Description of the Study Area}

The study area consists of two coal projects in Barjora police station area in Bankura district of West Bengal, India that is, Trans- Damodar coal project (study site 1) and Barjora north coal project (study site 2) (please refer to Figure 1). It lay in the extreme northern part of the Bankura District as well as Barjora Block and located on the right bank of the lower catchment of the river Damodar. This area consists of a wide plain of younger alluvium associated with $10-11 \mathrm{~m}$ thickness followed by sandstone of Barakar formation of Gondowana supergroup. It is known as valley fill surface and ranges from $78 \mathrm{~m}$ to $85 \mathrm{~m}$ in altitude (Banerjee, 1968; Bhattacharyya and Roy, 1982). The surface of the study area was under cultivation and covered with vegetation, but now the land is converted into an open cast coal mining track. The study area consists of surrounding villages of Barjora census town area which come under Barjora and Ghutgoria Gram Panchayet area of Bankura district. While Trans-Damodar coal project comprises of seven mouzas- Shalgara, Krishnagar, Kishoripur, Joysinghapur, Ronalejora, Bhagabanpur, Paharpur; Barjora north coal mine comprises of five mouzasBaguli, Barapukuria, Ghugoria, Monohar and Saharjora. Geographically, the study area extends within the latitudes of $23^{\circ} 23^{\prime} \mathrm{N}$ to $23^{\circ}$ $28^{\prime} \mathrm{N}$, and from $87^{\circ} 12^{\prime} \mathrm{E}$ to $87^{\circ} 19^{\prime} 09^{\prime \prime} \mathrm{E}$ longitudes (Figure 1). It is located approximately $3 \mathrm{~km}$ from Durgapur town, $23 \mathrm{~km}$ from Bankura town and $3 \mathrm{~km}$ from Barjora census town. 


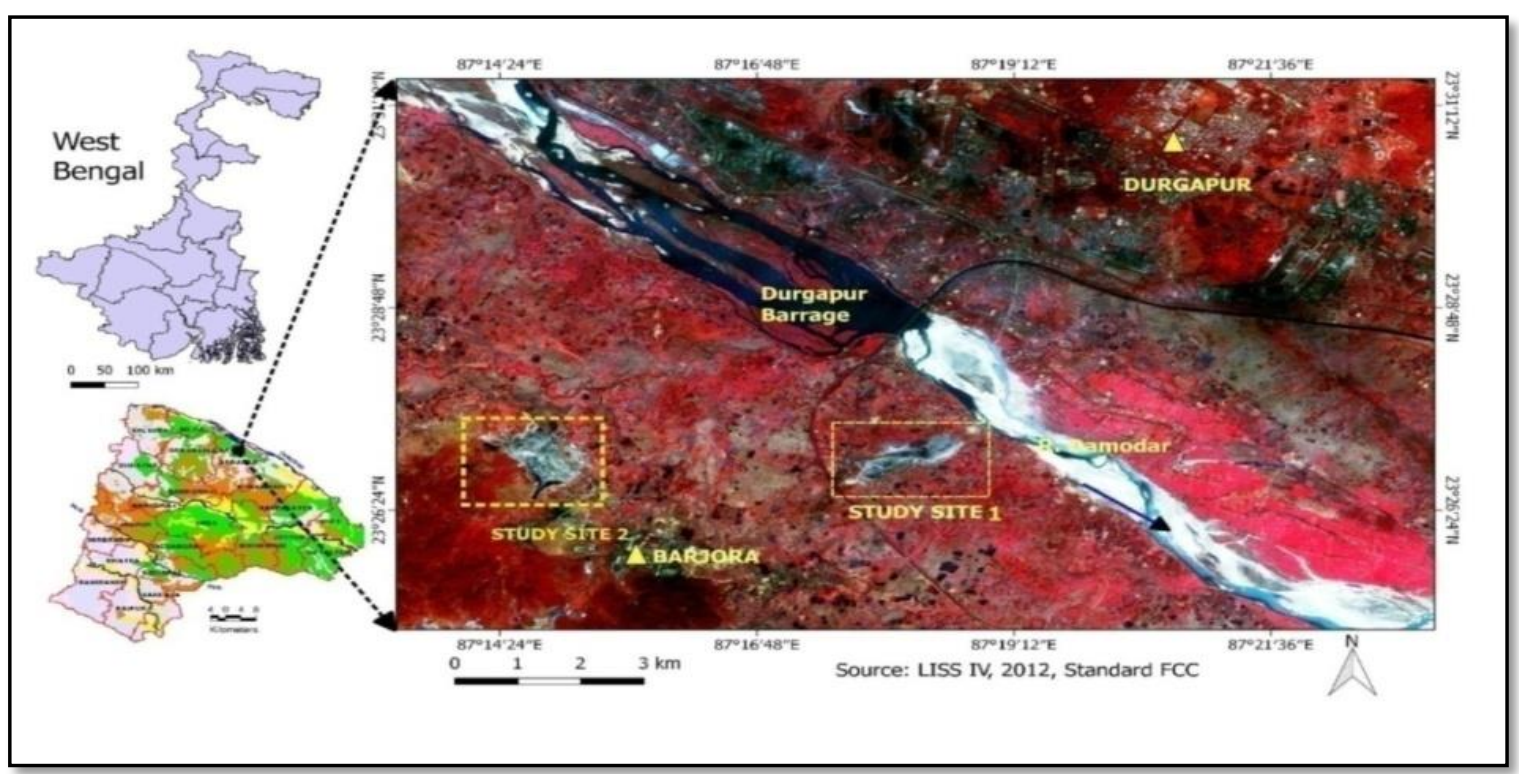

Figure 1: Location Map of the Study Area

Source: Prepared by the Authors with the help of LISS IV, 2012, Standard FCC, 2016

\section{Background of the Barjora Colliery}

Major coal layers found in the northwestern part of the Bankura district extends from the Mejia block to Barjora block across the Damodar River. This region contains coal seams of the Ranigang Gondowana system which is covered predominantly by alluvium, and the total reserve has been estimated to about 25 million tons (Banerjee, 1968; Bhattacharyya and Roy, 1982). Two open cast collieries have been newly set-up in Barjora area since 2010-2011. They are- (i) Trans-Damodar coal mine and (ii) Barjora north coal mine covering an area of $5.5 \mathrm{sq} . \mathrm{Km}$. and eight sq. Km. respectively (Figure 2). Barjora colliery lies in the southeastern part of the Raniganj coalfield governed by West Bengal Mineral Development Corporation Limited (WBMTDC).

It is important to note here that land acquisition is a major problem in India for any developmental work and resource-based activity. Coal mining action and land procurement are interrelated with each other only because distinctive kinds of mining works require large land to remove mineral from the earth's surface. The first extraction process was initiated by the Left Front Government of the state in the year 2005 (Figure 3). During this period, the villagers agitated because the government failed to fulfil their demands linked to jobs, land prices, infrastructure and others (Figure 6). This agitation, however, continues from 2005 until today. Because of the on-going protests, in September 2014, the Honourable Supreme Court of India had cancelled the order of the two coal projects. Hence, these two coal blocks remained inactive for about nine months (Figure 4). Although the Government had introduced re-allocation bill for the two cancelled coal blocks in June 2015, it has not been possible for the respective companies to run the mining activities smoothly and regularly due to on-going local agitation (Figure 6).

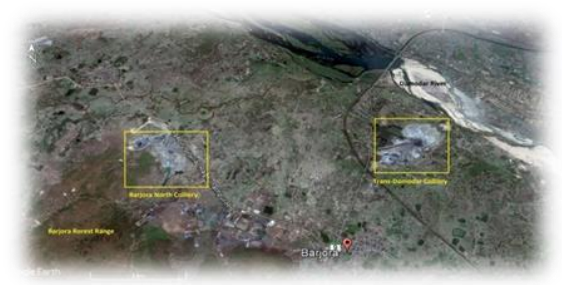

Figure 2: Two open-cast collieries at Barjora (Trans-Damodar and Barjora North) Source: Google Earth image (Image Date 8.11.2015, retrieved on 15.09.2017). 


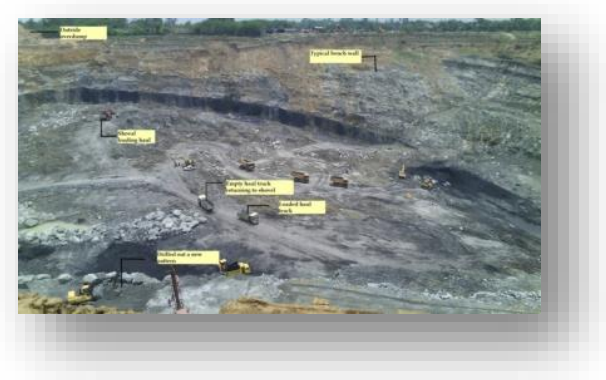

Figure 3: Active Coal Mine at Barjora Colliery

Source: Photograph Captured by the Authors during Field Survey, 2015-2017

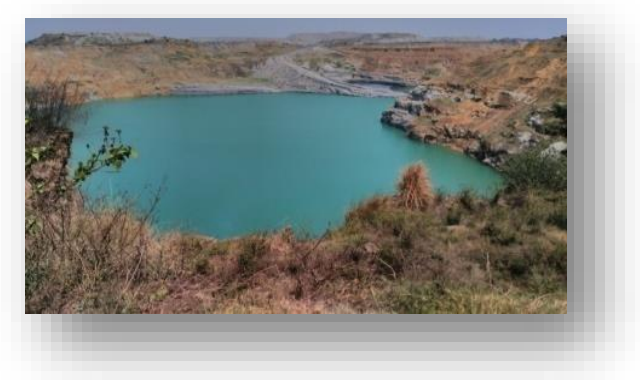

Figure 4: Inactive Coal Mine at Barjora Colliery

Source: Photograph Captured by the Authors during Field Survey, 2015-2017

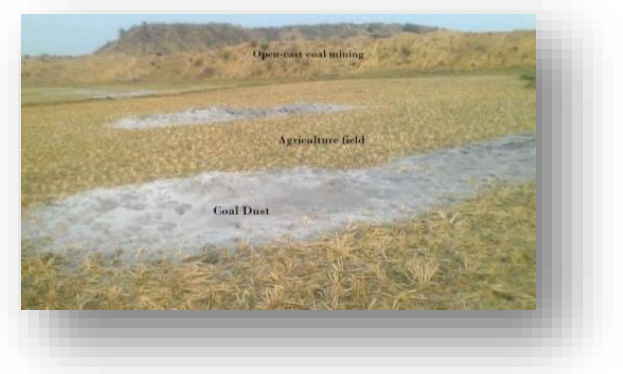

Figure 5: Coal Dust Stored in Agricultural Field

Source: Photograph Captured by the Authors during Field Survey, 2015-2017

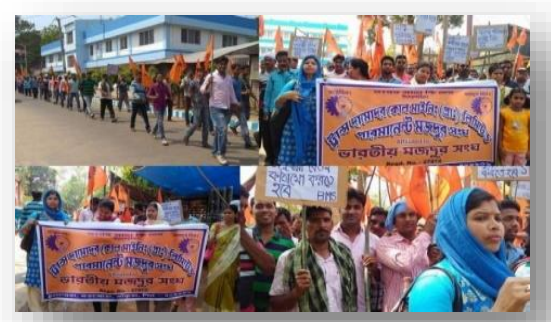

Figure 6: Agitation Rally at Barjora Colliery

Source: Photograph Captured by the Authors during the Field Survey, 2015- 2017

\section{Methods and Materials}

The study is primarily based on repeated empirical observation and perception survey through intensive fieldwork. To fulfil the objectives of the study, information has been collected from both primary and secondary sources. As primary data is one of the fundamental components in this research, it has been obtained from door to door survey, interviews using a structured questionnaire, group discussion and recall method. The secondary data have been collected from the 
panchayat office, Trans-Damodar Transport Welfare Society, census data, official records of mining companies. Before the field survey, related literature, various maps and toposheet $(73 \mathrm{M} / 3$ and $73 \mathrm{M} / 7)$ have been studied to understand the basic issues.

A pairwise ranking, a popular technique of 'Participatory Rural Appraisal (PRA) approach', is used to identify the major socio-economic activities in the study area. In this approach, comparative analysis has been used among all socio-economic parameters for developing the ranks of each parameter (Cavestro, 2003). Ranking has prepared on the basis of a sample population of a group consisting of 5 to 10 people according to their perception. 'Herfindahl- Hirschman index' (HHI index) is popularly used for indicating the measure of rivalry among various variable in the market economy, which is calculated using the following formula: $\mathrm{HHI}=\Sigma\left(\mathrm{Si}^{2}\right)$ [where $\mathrm{Si}$ is the market share of a firm in the market] (Woerheide, and Persson, 1993; Mishra, 2009). Here, the HHI index is used to measure the income diversification among the different mining and non-mining communities. After the $\mathrm{HHI}$ index, diversification is measured using the formula: $D$ $=1-H$ [Where $D$ is Diversification Index; $H$ is Herfindahl index]. Here, higher $D$ value indicates the higher diversification of income and viceversa.

Cropping Intensity has been used for analyzing the fertility pattern of agricultural land. The 'rotation value (R) of Ruthenberg' has been measured to find the cropping intensity Index of agricultural land. The formula of $\mathrm{R}$ factor is as follows: $R=(C \times 100) /(C+F)$, where $C$ is the cropping pattern in years; $F$ is the fallow period (Ruthenberg, 1976; Das and Mishra, 2015: b). Agriculture system is classified on the basis of Rvalue when R-value is greater than 66 ; it indicates that farming is permanent. But when Rvalue is in between 33 to 66 , it signals that the cultivated land has remained fallow and below 33 indicates shifting cultivation. But in intensive cultivation system, when the ' $R$ ' value exceeds 100; it indicates two or three crops are being practised in a year (Das and Mishra, 2015). 'Pvalue (probability value) has also been considered in the study for hypothesis testing. Pvalue' (probability value) of chi-square $(\chi 2)$ and t-test have been used to understand the difference in the significance of various attributes between mining communities and non-mining communities. When the $p$ value is less than the 'alpha' value (level of significance, it may be 0.01 or $0.05 \%$ level), the result is significant. When the $p$ value is higher than the alpha value, the null hypothesis is accepted, and the result is not significant.

In this research, six mining affected villages from two open-cast collieries have been selected on the basis of the spread of mining activities and its effect on the residents either directly or indirectly. The study has been conducted using a systematic random sampling method. The household selection of mining community was based on regular and genuinely affected communities through the collection of a detailed list of land donors from Barjora panchayat office and mining authority.

\section{Results and Discussion}

\section{Effects of Coal Mining on Diversified Sources of Rural Livelihood at Barjora Colliery}

Rural people of the study area are engaged mainly in nature-based livelihoods, and they are mostly self-employed. Before the commencement of the mining industry, the entire rural region of the Barjora coalfield was structured with agrarian activities. They were engaged in diversified rural livelihoods, for example, farming, fishing, off-farm activities, forest product collection, vendor, skilled and non-skilled labour, small business and collection of common property resources (CPR), etc. But the entire scenario had changed after coal mining activities were launched in 2010 and the productive agricultural land of the locals were taken away for mining activities, thereby, transforming the livelihood pattern of the residents and making them depend entirely on mining activities. Table 1 outlines the diverse sources of occupational structure, which witnessed drastic transformation when compared to pre-mining phase. Although mining is a profitable economic activity, it lacks the guarantee of job security. Rural residents of the are trying to adapt to this vulnerability. 


\begin{tabular}{|c|c|c|c|c|c|c|}
\hline \multirow[t]{2}{*}{ Primary Sources } & \multicolumn{4}{|c|}{ Mining Community } & \multicolumn{2}{|c|}{$\begin{array}{l}\text { Non- Mining } \\
\text { Community }\end{array}$} \\
\hline & $\begin{array}{l}\text { Pre- } \\
\text { Mining }\end{array}$ & $\ln \%$ & $\begin{array}{l}\text { Post- } \\
\text { Mining }\end{array}$ & $\ln \%$ & Persons & $\ln \%$ \\
\hline Agriculture & 58 & 64.44 & 7 & 7.78 & 31 & 62 \\
\hline Agriculture Labour & 11 & 12.22 & 0 & 0 & 9 & 18 \\
\hline Employment (Private Sector) & 7 & 7.78 & 2 & 2.22 & 2 & 4 \\
\hline Employment ( Govt. Sector) & 3 & 3.33 & 3 & 3.33 & 0 & 0 \\
\hline Business from Fixed Premises & 5 & 5.55 & 11 & 12.22 & 3 & 6 \\
\hline Skilled Wage Labour & 0 & 0 & 2 & 2.22 & 0 & 0 \\
\hline $\begin{array}{l}\text { Unskilled Non-farm Wage } \\
\text { Labour }\end{array}$ & 4 & 4.44 & 13 & 14.44 & 2 & 4 \\
\hline Industrial Labour & 0 & 0 & 0 & 0 & 3 & 6 \\
\hline Mining & 0 & 0 & 51 & 56.67 & 0 & 0 \\
\hline Others & 2 & 2.22 & 1 & 1.12 & 0 & 0 \\
\hline Total & $` 90$ & 100 & 90 & 100 & 50 & 100 \\
\hline \multirow[t]{2}{*}{ Secondary Sources } & \multicolumn{4}{|c|}{ Mining Community } & \multicolumn{2}{|c|}{$\begin{array}{l}\text { Non- Mining } \\
\text { Community }\end{array}$} \\
\hline & $\begin{array}{l}\text { Pre- } \\
\text { Mining }\end{array}$ & $\ln \%$ & $\begin{array}{l}\text { Post- } \\
\text { Mining }\end{array}$ & $\ln \%$ & Persons & $\ln \%$ \\
\hline Agriculture & 7 & 7.78 & 3 & 3.33 & 5 & 10 \\
\hline Common Property Resources & 31 & 34.44 & 4 & 4.44 & 21 & 42 \\
\hline $\begin{array}{l}\text { Unskilled Non-farm Wage } \\
\text { Labour }\end{array}$ & 1 & 1.11 & 19 & 21.11 & 3 & 6 \\
\hline Fishing and Allied Service & 13 & 14.44 & 0 & 0 & 5 & 10 \\
\hline $\begin{array}{l}\text { Goat Farm/Other Animal } \\
\text { Rearing }\end{array}$ & 14 & 15.55 & 0 & 0 & 9 & 18 \\
\hline Shopkeeper & 4 & 4.45 & 13 & 14.44 & 2 & 4 \\
\hline Vendor & 15 & 16.68 & 0 & 0 & 4 & 8 \\
\hline L.I.C Agent & 0 & 0 & 3 & 3.33 & 0 & 0 \\
\hline No Secondary Sources & 5 & 5.55 & 48 & 53.33 & 1 & 2 \\
\hline Total & 90 & 100 & 90 & 100 & 50 & 100 \\
\hline
\end{tabular}

Although livelihood does not only depend on one component, that is, income generation, but it is a fact that the earning sources are the basic components to construct sustainable livelihoods. However, when a single source of livelihood fails to meet the household necessities, it is natural for the households to diversify their sources of livelihood (Das and Mishra, 2015: a). During the pre-mining phase, the majority of respondents, that is, $64.44 \%$ respondents were engaged in the agricultural activities, and $12.22 \%$ were engaged as agricultural labour, which remained their primary source of income (Table 1). Thus, among the residents considered for this survey, around $87 \%$ depended on agriculture.

However, in the post-mining phase, their situation is entirely different $-56.67 \%$ of the surveyed households are now engaged in mining activities, which remains their primary sources of income. The introduction of the colliery was a whole new experience for the villagers. These new projects brought new hopes to the villagers. Almost 1,000 households had sold their lands to 
the miners for a considerable amount of money in the form of compensation depending on the amount of land together with a job offer to member(s) of a household for every six bighas (8026.8304 square metres) of land. But those households who had a land below six bighas (8026.8304 square metres), received monetary compensation, plus the permission to open a business in the colliery area. These agrarian villagers received a new form of earning in the mining sector against their loss of land. Although in the post-mining scenario, the mean household income has escalated when compared to the pre-mining phase, this has been possible in return of the loss of their valuable cultivable lands.

Before mining, agricultural lands were fertile and maximum people were engaged with agricultural activities. At that time agricultural land was in double-crop system, and the Rvalue $^{1}$ (83.33) also indicates the same. The main crops of this area were rice, mustard, sesame, and vegetables like pumpkin, cucumber, chilli, potato, etc. But after mining, most of the fertile land is converted into mining plot, and the quality of surroundings farming land has been degrading. In post-mining condition R-value is $62.5^{2}$ maintaining six-month fallow period. The cropping intensity of the farming land has plummeted, and farming activities have declined from primary sources of income to secondary sources of income. The research findings also brought to the fore that those local people who did not lose their farming land and had failed to accrue any form of benefits from the mining project, they too have lamented that their lands are losing its fertility status. Our research however observed that the surrounding agricultural fields are not in a favourable situation for agriculture due to increased dust pollution (Figure 5 ). In the post-mining situation, only $7.78 \%$ of the people are engaged in agricultural activities, and the category of agricultural labour have partially vanished from these villages. Logically, it can be argued that

\footnotetext{
${ }^{1} R$ value is $\{(2 * 100) /(2+0.4)\}=83.33$. Where $C$ is double cropped ( 2 ) cropping pattern, $\mathrm{F}$ is 4 month fallow period.
}

agricultural labour is now employed as unskilled non-farm wage labour (14.44\%).

In the pre-mining phase, the mining-affected households were engaged in different activities to accomplish secondary sources of income in addition to their primary sources to sustain a better livelihood. For example, about $14.44 \%$ of the mining-affected households were engaged in fishing and other allied services followed by 7.78 $\%$ in agriculture, $15.55 \%$ in goat farm and other animal rearing, $16.68 \%$ as vendors, $4.45 \%$ as shopkeepers and $34.44 \%$ used to earn some fixed income from CPR. Conversely, after the introduction of mining, these activities of secondary sources of income have dwindled; but coal mining industries provide an atmosphere for commercial activities. The findings reveal that approximately $12.22 \%$ of mining-affected households now engage in business activities, an increase from $5.55 \%$ in the pre-mining phase. Almost $17 \%$ of mining-affected households are involved in different mining-related activities as skilled and unskilled labour (Table 1).

On the other hand, in case of the non-mining communities, they are engaged in the same livelihood as before. $62 \%$ are still dependent on farming, and $18 \%$ of them are agricultural labour. Besides agriculture, they also have other secondary sources of income, that is, $42 \%$ of the sample households are involved in collecting CPR, $10 \%$ of respondents earn their primary income from fishing in the Damodar canal, and various ponds and $18 \%$ of sample of the respondents are engaged in animal rearing (Table 1). Interestingly, none of these nonmining communities is involved in these colliery projects because they are not land donors. But the biggest problem is faced by those who did not have their own lands and used to depend on the land of others to earn their livelihood. That is, amongst the non-mining community, some of them used to make their livelihood by working as daily labour at a wage rate of ₹90 per day. According to them, it is tough to work as daily

\footnotetext{
${ }^{2} R$ value is calculated by $\{(1 * 100) /(1+0.6)\}=62.5$. Where $C$ is single (1) cropped cropping pattern, $F$ is 6 month fallow period.
} 
contractual labour at the colliery project. This inequality of income (Kitula, 2004) among mining and non-mining communities has triggered social conflicts.

There are significant differences in agricultural activity between the pre-mining (64.44 \%) and post-mining $(7.78 \%)$ communities $(P=0.00<$ 0.01) which have been presented in Table 2 . Similarly, approximately $7.78 \%$ and $62 \%$ of surveyed respondents are agricultural labour in mining and non-mining communities respectively $(P=0.00<0.01)$. On the other hand, there are no significant differences in agricultural activity within the pre-mining and non-mining communities $(P=0.77>0.05)$. Even after mining, $62 \%$ of non-mining villagers are engaged in their earlier agricultural activities (Table 2).

Table 2: Community Involved in Agricultural Works at Barjora Colliery Area

\begin{tabular}{|c|c|c|c|}
\hline \\
\hline Community & Agricultural Works (Persons) & Non-Agriculture Works (Persons) & Total (Persons) \\
\hline Pre-Mining & $58(64.44 \%)$ & $32(32 \%)$ & $90(100 \%)$ \\
\hline Post-Mining & $7(7.78 \%)$ & $83(83 \%)$ & $90(100 \%)$ \\
\hline Total & 65 & 115 & 180 \\
\hline \multicolumn{4}{|c|}{$P=0.00<0.01$} \\
\hline Community & Agriculture Works (Persons) & Non-Agriculture Works(Persons) & Total (Persons) \\
\hline Mining & $7(7.78 \%)$ & $83(92.22 \%)$ & $90(100 \%)$ \\
\hline Non-Mining & $31(62 \%)$ & $19(38 \%)$ & $50(100 \%)$ \\
\hline Total & 38 & 102 & 140 \\
\hline \multicolumn{4}{|c|}{$P=0.00<0.01$} \\
\hline Community & Agriculture Works (Persons) & Non-Agriculture Works(Persons) & Total (Persons) \\
\hline Pre-Mining & $58(64.44 \%)$ & $32(35.55 \%)$ & $90(100 \%)$ \\
\hline Non-Mining & $31(62 \%)$ & $19(38 \%)$ & $50(100 \%)$ \\
\hline Total & 89 & 51 & 140 \\
\hline
\end{tabular}

Source: Prepared by the Authors from Field Survey, 2015-2017.

Note: Significant at $P<0.01$, non significant at $P>0.05$

\section{Income Diversification}

The Herfindahl- Hirschman index has been applied to measure the diversification of income by taking different occupational structure or sources of income (Table 3 ). It includes mining, agriculture, agriculture labour, business, government and private jobs, CPR collection and other activities. The diversified value of postmining condition $(D=0.78)$ is less than the premining condition $(D=0.81)$. Besides, the nonmining communities $(D=0.82)$ have more diversified sources of income instead of the mining groups ( $D=0.78$ ) (Table 3 ). After the introduction of mining, most of the households have a job in the mining project. They are not involved in other activities as mining companies have occupied their lands and they have no land to use for other purposes. So, they have no opportunity to earn money from different sources. But the situation was different before mining as the rural people were engaged in different activities.

\section{Table 3: The Herfindahl- Hirschman Index for Income Diversification}

\begin{tabular}{|l|c|c|}
\hline \multicolumn{2}{|c|}{ Table 3: The Herfindahl- Hirschman Index for Income Diversification } \\
\hline \multicolumn{1}{|c|}{ Community / Respondents } & HHI Index & Diversification Value (D) \\
\hline Pre-Mining Community & 0.19 & 0.81 \\
\hline Post-Mining Community & 0.21 & 0.78 \\
\hline Non-Mining Community & 0.18 & 0.82 \\
\hline
\end{tabular}

Source: Prepared by the Authors from the Field Survey, 2015-2017 


\section{Changing Scenario in Major Socio-Economic Activities}

As mentioned above, the main occupation of the villagers was agriculture in the pre-mining phase, which attained the first rank with a score of 8 (Table 4). Concerning this ranking order, agricultural labour occupied the second rank, followed respectively by CPR collection, animal rearing, vending, business, skilled and nonskilled wage labour, fishing and service. But as discussed above, the agricultural activities lost its importance after the beginning of coal mining activity in this area. In the case of TransDamodar coal project, the mining company acquired massive agricultural land (350 Hectares in Project 1). However, in the post-mining scenario, the majority of the respondents are working as mining labour. That is why mining activities gained the first rank scoring 6 (Table 5). The second rank is occupied by business, followed by different skilled and unskilled labour, shopkeepers, agriculture, and animal rearing and at last the CPR collection.

\begin{tabular}{|c|c|c|c|c|c|c|c|c|c|c|c|}
\hline \multirow[t]{2}{*}{ Socio-Economic Activities } & \multicolumn{9}{|c|}{ Socio-Economic Activities } & \multirow[t]{2}{*}{ Score } & \multirow[t]{2}{*}{ Rank } \\
\hline & 1 & 2 & 3 & 4 & 5 & 6 & 7 & 8 & 9 & & \\
\hline 1. Agriculture & $x$ & 1 & 1 & 1 & 1 & 1 & 1 & 1 & 1 & 8 & 1 \\
\hline 2. Employment & & $x$ & 3 & 4 & 5 & 6 & 7 & 8 & 9 & 0 & 9 \\
\hline 3. Business & & & $x$ & 3 & 5 & 6 & 7 & 8 & 3 & 3 & 6 \\
\hline 4. (Skilled/Unskilled Labour & & & & $x$ & 5 & 6 & 7 & 8 & 4 & 2 & 7 \\
\hline 5. Agriculture Labour & & & & & $x$ & 5 & 5 & 5 & 5 & 7 & 2 \\
\hline 6. Common Property Resources & & & & & & $x$ & 6 & 6 & 6 & 6 & 3 \\
\hline 7. Animal Rearing & & & & & & & $x$ & 7 & 7 & 5 & 4 \\
\hline 8. Vendor & & & & & & & & $x$ & 8 & 4 & 5 \\
\hline 9. Fishing and Allied Services & & & & & & & & & $x$ & 1 & 8 \\
\hline
\end{tabular}

Table 5: Pair-wise Ranking of Socio-economic Activities in the Post-mining Community

\begin{tabular}{|c|c|c|c|c|c|c|c|c|c|}
\hline \multirow[t]{2}{*}{ Socio-Economic Activities } & \multicolumn{7}{|c|}{ Socio-Economic Activities } & \multirow[t]{2}{*}{ Score } & \multirow[t]{2}{*}{ Rank } \\
\hline & 1 & 2 & 3 & 4 & 5 & 6 & 7 & & \\
\hline 1. Agriculture & $x$ & 2 & 3 & 4 & 1 & 1 & 7 & 2 & 5 \\
\hline 2. Mining & & $x$ & 2 & 2 & 2 & 2 & 2 & 6 & 1 \\
\hline 3. Business & & & $x$ & 3 & 3 & 3 & 3 & 5 & 2 \\
\hline 4. Wage Labour (Skilled/Unskilled) & & & & $x$ & 4 & 4 & 4 & 4 & 3 \\
\hline 5. Common Property Resources & & & & & $x$ & 6 & 7 & 0 & 7 \\
\hline 6. Animal Rearing & & & & & & $x$ & 7 & 1 & 6 \\
\hline 7. Shopkeeper & & & & & & & $x$ & 3 & 4 \\
\hline
\end{tabular}




\begin{tabular}{|c|c|c|c|c|c|c|c|c|c|c|c|}
\hline \multirow[t]{2}{*}{ Socio-Economic Activities } & \multicolumn{9}{|c|}{ Socio-Economic activities } & \multirow[t]{2}{*}{ Score } & \multirow[t]{2}{*}{ Rank } \\
\hline & 1 & 2 & 3 & 4 & 5 & 6 & 7 & 8 & 9 & & \\
\hline 1. Agriculture & $x$ & 1 & 1 & 1 & 1 & 1 & 1 & 1 & 1 & 8 & 1 \\
\hline 2. Agriculture Labour & & $x$ & 2 & 2 & 2 & 2 & 2 & 2 & 2 & 7 & 2 \\
\hline 3. Business & & & $x$ & 3 & 5 & 6 & 7 & 8 & 3 & 2 & 7 \\
\hline 4. Wage Labour (Skilled/Unskilled & & & & $x$ & 5 & 6 & 7 & 8 & 4 & 1 & 8 \\
\hline 5. Industrial Labour & & & & & $x$ & 6 & 7 & 5 & 5 & 4 & 5 \\
\hline 6. Common Property Resources & & & & & & $\mathrm{x}$ & 6 & 6 & 6 & 6 & 3 \\
\hline 7. Animal Rearing & & & & & & & $x$ & 7 & 7 & 5 & 4 \\
\hline 8. Vendor & & & & & & & & $x$ & 8 & 3 & 6 \\
\hline 9. Fishing and Allied Services & & & & & & & & & $x$ & 0 & 9 \\
\hline
\end{tabular}

As the mining company did not acquire their farming land, agriculture is the major occupation among non-mining communities (Table 6). Even after mining, the non-mining livelihood is still nature-based and diverse.

\section{Impact of Mining on Women's Livelihood}

Before mining, while some women of the study area were engaged in the household related activities and fulfilled their livelihood necessities, some of them were engaged in the collection of CPR; while some others were engaged in the industrial sector and brick industry as industrial labour. While some women spent their valuable time in the agriculture field; few others used to sell vegetables in the Barjora market. Especially, women from Barapukuria and Manohar mouza used to prepare leaf plates from sal (Shorea robusta) leaves and sell it in the nearby market. Forest used to be one of the major sources of income to these women communities. Sal leaves are the prime forest products of this forest range. Another forest products collected from this forest are mohua (Madhuca longifolia), sal seeds, kendu (Diospyros melanoxylon) leaves, edible mushrooms, fruits of amloki (Phyllanthus emblica), bahara (Terminalia bellirica) and haritaki (Terminalia chebula), etc. Mohua is used as vegetables, sal seeds for beedi (thin cigarette) making and different mushrooms like kurkuri chatu (Agaricus bisporus) and Poal Chatu (Volveriella volvacea) are economically important. This observation partially bears resonance to the research findings of Roy and
Samanta (2018) who have demonstrated as to how the localised non-farm economy of beedi and silk have driven the growth of the Census Towns in Murshidabad District, West Bengal. However, in the post-mining phase, the significance of all the activities of women's communities has dwindled. While the majority of them have become jobless, some of them are engaged in mining activities as daily labour.

\section{The Risk behind Adopting New Livelihood}

There are many examples in India demonstrating that after the commencement of a development project, the company had to seize the production for some time, and it took nearly three decades to get back to work (Oskarsson, 2011). Because of this, an estimated $42 \%$ (1.4 million mining and quarrying households) have become marginal or living in extremely vulnerable conditions due to their insecure jobs. Here, the vulnerability refers to the harmful conditions to which a human being is exposed to and the degree of exposure to the risk of the households (DFID, 2001). Due to their vulnerability, affected households are unable to spend sufficiently on their health, education, food, etc. and they suffer from different health diseases due to unhealthy air quality, dust pollution, noise pollution and low quality of water which is caused by mining (Oskarsson, 2011).

Similarly, the major problem began in the study area when coal mining projects suddenly had to seize their production in June 2015 (Figure 4). Although the coal company resumed the 
extraction process; the process of extraction and associated mining activities faced disruption unsettling local issues and the protests. The key demands triggering the agitation (Figure 6) are increment in their salaries, infrastructure development and healthy rehabilitation programme. Besides, the rally demands a permanent job guarantee alongside job benefits from the company based on the labour rules of coal-mining workers levied by the central government. During the survey, it was observed that with the introduction of mining, while some people have been involved in regular jobs, some had started various businesses, and the overall scenario of society began to improve. But following the disruption, the situation is getting worse, with people losing their jobs and business revolving around the mining projects had to be ceased. Closing down of these projects can be described as income shocks to the people involved here. Almost 300 families are facing these problems after losing their land and buying vehicles for transporting business. As the coal extraction process is not continuing regularly, they have to sell their vehicles. Now, they have no land, no job, and no vehicles to continue their business in the future. Apart from this, the poor people too, who served as daily labour in the colliery, are in total loss of their working opportunity too.

\section{Conclusion}

The study set out to examine the impact of the Barjora colliery area of Bankura district of West Bengal. Although, the mining project proved to be beneficial after it was launched in 2010, as soon as the activities of the colliery became disrupted, the vulnerability of the people has started pushing the villagers into poverty squalor. While this study is limited to the colliery of Bankura district, the findings would be useful not only for other similar projects of West Bengal but also for the entire country. The results of this research could also be helpful for a future longitudinal study.

\section{References}

Banerjee, A.K. (1968). West Bengal District Gazetteers, Bankura. State Book Depot: Calcutta (State Editor).
Bhattacharya, A.P. and Roy, S.K. (1982). Palynology of the lower Gondwana Sedimentary deposits in Bankura deposits, Ph.D. Thesis, University of Burdwan, West Bengal, India, p. 4-7.

Cavestro, L. (2003). PRA-Participatory Rural Appraisal Concepts Methodologies and Techniques, Universita' Degli Studi di Padova Facolta' di Agraria, p. 26-38. Retrieved from https://liberiafti.files.wordpress.com/2013/ 08/cavestro_participatory-rural-appraisalconcepts-methodologies-techniques.pdf

Central Mine Planning \& Design Institute Limited (CMPDI), (2016). Annual Report \& Accounts 2015-16, CIN: U14292JH1975GOI 001223, A Subsidiary of Coal India Limited, Ranchi. Retrieved from http://www.cmpdi.co.in/accounts/CMPDIA nnualReport2015-16.pdf

Chambers, R. and Conway, G.R. (1992). 'Sustainable Rural Livelihoods: Practical Concepts for the 21st Century', Discussion Paper 296. Brighton, UK: Institute of Development Studies, p. 6. Retrieved from https://opendocs.ids.ac.uk/opendocs/bitstr eam/handle/123456789/775/Dp296.pdf

Das, N. and Mishra, N. (2015: a). Assessing the Impact of Coal Mining on Diversified Sources of Rural Livelihoods: A Case Study in the Ib Valley Coalfield Area of Western. International Research Journal of Social Sciences, 4(6), p. 83-88.

Das, N and Mishra, N. (2015: b). Socioeconomic Impact on Rural Livelihood on Rural Communities: A Study of the $\mathrm{Ib}$ Valley Coalfield in Orrisa. Ph.D. Thesis, National Institute of Technology, Rourkela, India, p. 125-138. Retrieved from,

http://ethesis.nitrkl.ac.in/6913/1/Nabani ta_509HS304_PhD_2015.pdf

DFID (2001). Sustainable Livelihoods Guidance Sheets. Department for International Development, London. Retrieved from http://www.livelihoodscentre.org/documen ts/20720/100145/Sustainable+livelihoods+ 
guidance+sheets/8f35b59f-8207-43fc-8b99df75d3000e86

Ellis, F. (1998). Household strategies and rural livelihood diversification, The Journal of development studies, 35 (1), p. 38.

Frankenberger, T. (1996). Measuring household livelihood security: An approach for reducing absolute poverty. Paper prepared for the Applied Anthropology Meetings, Baltimore.

Jones, T. (1993). The role of environmentalimpact assessment in coal production and utilization. Natural Resources Forum, 17 (1993), p. 170-180.

Kitula, A. G. N. (2004). The environmental and socio-economic impacts of mining on local livelihoods in Tanzania: A case study of Geita District. Journal of Cleaner Production, 14(34), p. 405-414.

Krantz, L. (2001). The Sustainable Livelihood Approach to Poverty Reduction, An Introduction. Swedish International Development Cooperation Agency, Stockholm, Sweden.

Mishra, P.P. (2009). Coal Mining and Rural Livelihoods: Case of the Ib Valley Coalfield, Orissa. Economic and Political Weekly, Vol. XLIV NO (44), p. 117-123.

Oskarsson, P. (2011). " Jobless Opening: The Expansion of open cast coal mining at the expense of rural livelihoods in the Godavari valley of Andhra Pradesh", A report prepared by MORE (Motivational Organisation for Rural Education), Manuguru, Andhra Pradesh). Oxford University Press, p. 75.
Reardon, T., Berdegué, J., Barrett, C. B., Stamoulis, K., (2006). Household Income Diversification into Rural Nonfarm Activities, Baltimore: Johns Hopkins University Press, p. 1-26.

Roy, K., \& Samanta, G. (2018). Spread Effects vs. Localised Growth: The Case of Census Towns in Murshidabad District. Space and Culture, India, 6(3), 97-109. https://doi.org/10.20896/saci.v6i3.327

Ruthenberg, H. (1976). Farming Systems in the Tropics, Second edition. Oxford University Press, Oxford, UK.

Scoones, I. (1998). Sustainable rural livelihoods: a framework for analysis. IDS working paper, 72, Brignton, p. 9-11. Retrieved from

https://www.staff.ncl.ac.uk/david.harvey/AEF8 06/Sconnes1998.pdf

Siddiqui, M.Z. and Lahiri-Dutt, K. (2015). Livelihood s of Marginal Mining and Quarrying Households in India. Economic and Political Weekely, Vol L NoS 26 \& 27, p. 27-32.

Woerheide, W. and Persson, D. (1993). An Index of Portfolio Diversification. Financial Services Review, 2(2), p. 76-77. Retrieved from,http://citeseerx.ist.psu.edu/viewdoc/ download?doi=10.1.1.399.1779\&rep=rep1 \&type $=p d f$

World Coal Association, (2015). Coal Facts 2015. London. Retrieved from, http://www.worldcoal.org/file_validate.p hp ?file=Coal\%20Facts\%202015.pdf 